\title{
Wine tourism in Italy
}

This article was published in the following Dove Press journal:

International Journal of Wine Research

28 April 2015

Number of times this article has been viewed

\section{Donatella Cinelli Colombini}

Orcia Doc Wine Consortium, Rocca d'Orcia , Italy

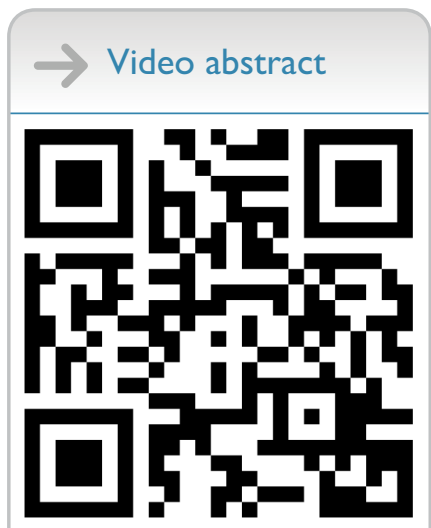

Point your SmartPhone at the code above. If you have a QR code reader the video abstract will appear. Or use: http://dvpr.es//3FoFOV
Correspondence: Donatella Cinelli Colombini

Casato Prime Donne, Loc Casato I7, 53024 Montalcino SI, Italy

Tel +39057784942 I

Fax +3905 77849353

Email donatella@cinellicolombini.it
Abstract: This text includes the history of wine tourism in Italy since 1993, when the first edition of the event "Cantine Aperte" (Open Cellars), Wine Day, took place. The movement grew from the initial 25 wineries to the 21,000 that participate today in opening their doors to the public, while visitors grew in numbers from a couple of hundred, 20 years ago, to the current 4 to 6 million. Wine tourists can be divided into four main groups: wine tourists by chance, classic wine tourists, talent scouts, and lovers of luxury. Each group is examined according to its consumption, its conduct, and its expectations. Wine tourism in Italy boasts around 170 territorial networks: "Strade del Vino" (wine routes) regulated by law. After an initial pioneer phase during which preexisting wineries adapted to the growing number of tourists, modern-day wineries were created with bespoke areas for the welcoming of visitors. Wineries in Italy can be classified into the following main types: "functional wineries" that concentrate on productive efficiency; "cathedrals" - renovated historic buildings or modern "starchitecture" designs in which esthetics play an important role; wineries with a "strong identity" linked to the owner or wine producer with the special imprint of his or her personal wine making passion. Other features of Italian wine territories such as food and wellness centers not to speak of the ever present cultural heritage also play a part in attracting wine tourists. Lastly, an evaluation is made of business and communication aspects with a specific reference to the use of the web.

Keywords: wine tourism, Italian wineries, winery tours, wine roads of Italy

\section{History of wine tourism in Italy}

In the past years, wine tourism has changed in Italian wineries and as a result the entire economy of the wine territories. When the first edition of "Cantine Aperte" (Open Cellars) was organized in 1993, an event that spread wine tourism all over Italy, hardly more than 20 wineries in the whole of Italy were accessible to tourists, with a total turnover of around 200,000 Euros per year. The first 100 Tuscan wineries that agreed to open their doors to the public on that Sunday May 9, 1993, triggered a kind of revolution. The tourist attraction of wine production areas had become evident, and competitors joined in a common objective that could not have been reached individually: the visibility that stems from the very size of an initiative - the critical mass that makes news attracting the attention of TV channels and newspapers.

After the first edition of the "Cantine Aperte" day, the event was repeated during the following years; first in seven regions of Central Northern Italy, then all over the country, and finally in an effort to render the event international, the model was launched as a sort of worldwide "Wine day", a welcome-to-wineries day. Unfortunately, this project was not successful. 
The Wine Tourism Movement, the association that organizes "Cantine Aperte", printed brochures, promoted communication, and above all taught producers how to organize sales, tours, and tastings for visitors. Since 2007, an increasing number of wineries decided to stay open all year round. From then on the Tourism Movement's efforts concentrated on encouraging a warm welcome by qualified staff. The Wine Tourism Movement (MTV) still exists and also promotes other events apart from "Cantine Aperte". August 10 - the feast of San Lorenzo - was chosen as the day of "Calici di stelle" - (wine glasses of stars) for open-air tastings in wineries and in the villages of wine-producing regions. The event is mostly for young consumers and is organized together with the Associazione Nazionale Città del Vino. Other events take place during the grape harvests and at Christmas time.

Since 1999, a law that regulates the Wine Routes also financed the birth of more than 179 territorial networks. Unfortunately, only about 20 are fully functional and able to generate income while most of them are merely administrative decrees. In the absence of an Italian Ministry of Tourism, wine tourism is regulated by the regions, but wine tourism and the wine routes have always fallen between two areas: agriculture and tourism with the result that neither of them is efficiently managed. There is no such thing as national coordination to promote and further the sale of wine as a "tourist product" able to dictate minimum standards of income, as there are no systemic studies capable of drawing up an exact picture of the situation.

The two national organizations that are involved in wine tourism are the Movimento del Turismo del Vino (Wine Tourism Movement), which counts 1000 wineries, and the Associazione Nazionale Città del Vino, which refers to the the townships of wine areas. Both of them are highly committed to their work and are present in all the Italian regions. The page on wine tourism in the government website http://www.italia.it refers to these two organizations for any information.

As always, rapid growth has its pros and cons, and in fact, the number of wineries equipped for hosting people is low. Of the 21,000 wine estates with a shop, only 1000 boast of trained multilingual staff, rest rooms, a tasting hall, an informative recreational activity, and a well-equipped shopping area.

\section{Who are the tourists of Italian wineries and what are they looking for}

Foreign visitors of Italian wineries are estimated at between 4 and 6 million per year with an annual rise of $3.6 \%$ - clearly higher than general Italian tourism that is currently going through a difficult time. For 2 years now, Italy has seen its flow of Italian visitors decrease while the 46 million foreign tourists, despite their increase of $1.9 \%$ in 2013 , are not enough to counterbalance the decrease in domestic tourism.

The data available for evaluating business generated by wine tourism is very vague and there are no in-depth studies. All the experts of this sector refer to the Osservatorio del Turismo del Vino, drafted by Censis Servizi for the Associazione Città del Vino, which indicates a turnover of between 3 and 5 billion Euros depending on whether only the business in the wineries is taken into account or the entire income created by visitors of wine regions.

The Osservatorio points out how wine on its own does not generate tourism. The influx arises when prestigious bottles are produced in particularly beautiful intact areas. The landscape factor is clearly crucial and linked to respect for the environment and cultural aspects. Visitors perceive wine tasting as a complement or indeed as part and parcel of the land they are in, comparable to visiting a medieval castle or a 16 th century villa. It is not surprising that the quality of the territory is at the top (23\%) of the factors that influence the choices of wine tourists, coming before culture (19\%), wine and food (17\%), and the wine itself $(13 \%)$. There is an inextricable link between wines and they come from a bond that the winery owners aim to convey both in the welcoming of guests and in the wine tastings.

The Italian wine tourist is generally male (61.3\%) between 30 and 50 years of age. He travels as part of a couple or with a group of friends (source Centro Studi turistici Cst 2012 for Movimento del turismo del Vino). ${ }^{1}$

Even if they are all called wine tourists, $86 \%$ of Italian wineries visitors are in fact excursionists, ie, people who travel from morning till evening within a radius of $200 \mathrm{~km}$ from their home. Only 14\% of them spend the night in the wine area, and of these, one half stick to the weekend for their travel (WineNews data 25 May 2012). The quota of people who spend more days is marginal and above all foreign.

Italy is the prime destination for tourists whose holidays focus on wine-tastings and cuisine. Their destinations vary by culture. German-speakers gravitate to the northeast of the country - Trentino and the Alto Adige, Friuli, Venezia Giulia Veneto - whereas English-speakers definitely prefer Tuscany. Wine is also an important consideration for tour operators $66 \%$ of them. Statistics compiled in 2010 indicate that $23 \%$ of 
the Europeans and $43 \%$ of the Americans featured "tasting" destinations in their brochures. ${ }^{1}$

Visitors to Italian wineries fall into four general categories:

- Casual or spontaneous tourists, who stop at a winery by chance

- Dedicated oenophiles

- Wine scouts and reporters

- Lovers of luxury

\section{Wine tourists by chance}

On the whole, casual tourists are not educated about wines. They are often on a restricted budget. They probably only know about a few mainstream labels (eg, Chianti) advertised in their local media and available in their local shops. They need the reassurance of a known commodity. Price, convenience, and tradition are important to them. What best appeals to them is a brief group tour, enlivened by entertaining anecdotes, and short on technical and gourmet jargon. The wine "tourists by chance" are also interested in typical food. Sampling the cuisine of local restaurants is more appealing to them than tastings at a winery. Most of this demographic stays in cities or coastal towns near wine areas. Some travel by bus. For that group, it helps to organize a winery visit as part of a tour focused on art and monuments. Many travel agents leaven an art-rich urban tour with a day in the countryside, so as not to overwhelm their clients with too many churches, museums, and old masters. These travelers tend to be older or retired people, not seasoned travelers. They appreciate the diversion of a country jaunt, especially when it includes a delicious lunch in a farmhouse restaurant, irrigated by a famous wine, in a beautiful and historic location.

\section{Dedicated oenophiles}

These are the majority of winery visitors - between one and half to two million a year. The fame of the winery is essential to them. They are interested in prestigious, rare, and/or new wines, and they are also prepared to spend freely on them. They tend to be sophisticated and individualistic. So they hate group tours and are thrilled to meet the producer or wine-makers. They have a strong preference for expert guidance in the tasting of an experimental vintage - and for the boasting privileges of having been the first in their circle to discover it. Many in this demographic cultivate their palates by taking sommelier courses (widely available, in Italy, to lay people). They read gourmet magazines and blogs, and, above all, wine guidebooks. (These are plentiful in Italy, too.) Technical tours by competent staff appeal greatly to them. That said, these are picky and sometimes prickly guests. They like to show off their knowledge and may "test" the bona fides of their guides. Oenophiles prefer wine tastings with four or more vintages. (Two samplings are fine for the casual tourists.)

Included in this group are professionals in the wine business - merchants, restaurateurs, sommeliers, and importers. Their tourism is purposeful. They visit wine regions to keep up with new trends and to forge personal relationships with the producers of the wine they sell. Another subgroup in this category are the "foodies", who prize, and can judge, superior cuisine. They shop for and sample first-rate foodstuffs of local origin. The highlights of their vacations involve meals in starred restaurants, cooking classes with well-known chefs, and exclusive tastings.

Here, too, the categories vary among nationalities. German-speakers tend to come with their own cars and return to the same wineries year after year. They prefer small vineyards owned by vintners with whom they develop friendships. North Americans, on the other hand, prefer organized tours and often book them before leaving home. Usually, the excursion to a vineyard takes place in a minivan for eight to 12 people, with a driver who is a wine expert. It lasts 7 hours and includes two wineries and a traditional meal. Spring and autumn are the peak seasons for this group. The going rate for such tours is $130-170 €$ per person. For the individualists - couples, friends, or family groups - who prefer a car and driver, the average price of an excursion is 500-700€.

Most wine tours get booked on the Internet and are concentrated in Tuscany, the Veneto, Piedmont, and Sicily. Minibus or private tours tend to be the rule in Tuscany.

\section{Wine scouts and lovers of luxury}

These are really two separate groups, although they share an affinity for exclusive access to wineries, their owners, and/ or new wine making techniques. Here, however, they divide. The scouts are highly discriminating, and they understand the technology, but can often not afford the wines. The luxury tourists can afford the wines, but may not understand their subtleties. Wineries need to coddle this demographic. It is the scouts who discover and popularize new trends. They report back to wine journalists and important sectors of the trade. The ultra-rich spend a fortune on the highest end wines, those in which wineries have the biggest investment No group tours for EITHER of them, but a focus on novelty, experiment, great vintages from the past, and meet-and-greets with owners and wine makers. Tastings should include a great variety of bottles, and the highest possible level of exclusivity in the manner and settings in which they are offered. 


\section{Complementary offers}

The wine tourist business has, in recent years, been diversified and sophisticated. Twenty years ago, efforts to increase wine tourism focused on viniculture and on the creation of museums such as the Museo del Vino in Torgiano (Umbria) or the Museo del Vetro da Vino at Banfi (Tuscany). In the last few years, investments have been focused on hotels, restaurants, and other services.

"Destination wine weddings" have also increased greatly in popularity for visitors to Italy. The winery becomes the setting for the wedding banquet, and sometimes even for the ceremony. Nearly all destination-wedding planners have Italian wineries in their venue portfolios. Another new trend is the "Vespa" tour, a romantic holiday for adventurous couples who rent a motor scooter and explore the countryside. The scenic wine country in nearly every Italian province is a magnet for such tourists, who stay at local inns or agriturismos.

"Themed" guided tours have also increased in popularity. They peak at the vendemmia - the grape harvest season in October. Tourists choose a few key wineries, in different regions, tour their cellars and bottling facilities, and enjoy minicourses on viniculture, often with overnight accommodations on the estate.

Another new trend involves "wellness" vacations. Vinotherapy, cross-country walks or hikes, spa treatments, thermal baths, bicycle tours, and local cuisine, with organic wines, at picturesque restaurants, are aspects of this trend.

The Coldiretti association of cultivators has been highly successful with an awareness campaign for "km 0" food, meaning cuisine based on the most local products (zerokilometer distance away) and their authenticity of ingredients and preparation.

Finally, the last and perhaps most successful innovation for the wine tourist industry is represented by the growth of cooking schools. There has been an increase in authentic Italian cooking classes, partly thanks to their popularity on television, but partly because celebrity chefs have such prestige and earn such high salaries. Many wineries host such schools, and part of the curriculum includes wine education and tastings.

Organized events have had an important role in increasing wine tourism. Every wine city hosts at least one, and often several, a year. They are more like film festivals, or literary festivals, than they are like the tastings or tours of old. This tendency is so common all over Italy that technicians now speak of a promotion that has been "festivalized". The economic crisis has, however, taken a toll on these events. It has made careful planning on a focused demographic, offering them a memorable experience, the prime consideration. In the current climate, it is advisable to restrict such occasions to the oenophiles, the luxury lovers, the scouts - the connoisseurs, in other words - best able to appreciate the charm of the estate or the appellation. And best able to spread the word.

\section{Wine tourism offers - destinations and wineries}

All lists count Tuscany as Italy's prime wine destination. The Travellers' Choice Award 2012, The Wayn Award 2013, and major social media platforms for travel consider it first in the world. Huffington Post 2013 and USA Today 2014 grade it respectively in sixth and seventh place. Whatever the score, Tuscany seems to be among the historic wine destinations least vulnerable to competition from newer locales like the Okanagan Valley in British Columbia and Maipo in Chile. Here it is worth a note of caution about the lists. Perennially popular areas like Champagne and Alsace have practically disappeared from them, while in reality, they still welcome hordes of tourists. This paradox indicates that the lists focus on novelty for the few, not mass popularity, and that they penalize destinations perceived as too crowded or commoditized.

Tuscany offers wine tourists the four things they prize most dearly: spectacular landscape, high culture, excellent food, and great wines. The network of hotels, country inns, and restaurants of good or excellent quality supports the industry throughout the province, in its cities, towns, and villages. The large number of antique fairs, art festivals, concerts and other cultural events, the celebrities associated with Tuscany (from Prince Charles to Sting), the luxury shopping - and the luxury outlet shopping (Gucci, Prada, and Cavalli) - all help to consolidate Tuscany's supremacy.

In 2014, the vineyards in Langhe (Piedmont) were named a World Heritage site by UNESCO. This designation follows the one given, in 2004, to the Val d'Orcia (Tuscany), an area that includes the Brunello di Montalcino region. For the Barolo area, this is an incentive to develop wine tourism and to coordinate it with the opening of new hotels in renovated historic buildings. Italian wine lovers, motivated by the UNESCO honor, have flocked to Langhe, catapulting it to first place as a wine destination in the survey conducted by WineNews for Vinitaly 2014, (the preferred destinations were Langhe, Chianti, Franciacorta, Alto Adige, Montalcino, and Valpolicella).

Until 10 years ago, new wineries found it challenging to create facilities for tourists - ie, a tasting hall and retail 
store. Most of the wineries created in the last few years have included them. There is now a widespread awareness of wine tourism as a source of income and liquidity. For this reason, siting a winery is a decision of utmost importance. It should ideally be near tourist hubs. It should also, ideally, have the possibility for creating a restaurant, accommodations with private baths, a cooking school, and even an event space for conventions, concerts, or weddings.

Obviously, the new wineries offer services that are better organized, but they are not necessarily more charming than the older wineries. The irony is that overmarketing can be its own worst enemy. Thoughtful tourists (including the richest ones) prize the authentic character of the traditional locales. A processed experience is like processed food, and their palates are too sophisticated for it. They still come to Italy seeking a connection with real Italians who work the land, make their own wine, and respect their timeless heritage. So small wineries - the majority in Italy - may be the "underdogs" in terms of capitalization and traffic, but they have a real advantage among the more discerning wine tourists.

Italian wineries open to the public, which are new or have renovated facilities, fall into to two categories.

\section{Functional}

These include the best wine making with the greatest efficiency. Everything works and nothing excites.

The great private or cooperative wineries are part of this group. Usually, they are modern and full of technology and stainless steel. In many cases, at least some of the wines are of high quality, but the coldness and mechanization is off-putting.

\section{Monumental}

These are characterized by expensive construction materials, famous architects, and luxury decor. These wineries impress, but they have also proliferated to a bewildering degree. And they tend toward grandiosity.

- Ceretto, Barolo chapel with frescoes by David Tremlett and Sol Lewitt

- Terre Moretti, Petra winery Suvereto LI by Mario Botta

- Antinori, Campo al Sasso winery in Bolgheri by Gae Aulenti

- Panerai and Rothschild, Rocca di Frassinello winery in Gavorrano GR by Renzo Piano

- Gaja, Cà Marcanda winery, Castagneto Carducci, LI by Giovanni Bo
- Distilleria Bartolo Nardini, Bassano del Grappa VI by Massimiliano Fuksas

- Tarminn in Termeno Alto Adige, by Werner Tscholl

- Marchesi dè Frescobaldi, L'ammiraglia, Magliano in Toscana, GR, Piero Sartogo and Natalie Grenon

- Feudi di San Gregorio, Sorbo Serpico, Hikaru Mori-Zito

- Lunelli, Carapace winery, Montefalco, PG, Arnaldo Pomodoro

- Antinori, Cantina del Chianti Classico, Bargino, Archea Associati - Marco Casamonti.

\section{"Starchitecture"}

This is a grand space designed by a big name - plays an important role in determining the appeal of a winery, but not the only role. Here I will describe three exemplary estates: the Florio winery, in Marsala, Sicily; and two Tuscan destinations, the Castello di Brolio, near Siena; and Antinori, in Chianti.

The latter, a few kilometers from Florence, is a striking marriage of modernism to the Tuscan Renaissance tradition embodied in buildings by Brunelleschi, Leon Battista Alberti, and Arnolfo di Cambio. It is an undulating concrete structure designed by Marco Casamonti, of the Florentine firm Archea Associati, and it won the archdaily.com contest in the category of "Industrial Architecture". (This website showcases the work of the world's foremost architects, and last year, it featured a number of distinguished wineries, including Cheval Blanc, in France, designed by Christian de Portzamparc, and the Faustino Winery, in Spain, a masterpiece by Norman Foster.) The building symbolizes Antinori's twofold commitment to tradition and innovation: in its investment in viniculture and terroir and in its campaign to heighten brand awareness. The luxury wines of Antinori already enjoy worldwide fame, but the company isn't resting on its laurels. It has made both its winery and its evolving products a "must" for any serious wine tourist.

The Florio wineries in Marsala, in the province of Trapani, are the oldest Italian example of a large wine making enterprise able to create a global profile. They were founded in 1833 and modeled on those of two Marsala-producing English rivals, Woodhouse and Ingham and Whitaker. They played an important part in the landing of Garibaldi's followers that led to the liberation of Sicily and its unification with the nascent Kingdom of Italy. Garibaldi visited the Florio family, and his gifts to them are still on display at the winery.

After a period of decline in the 20th century, the Cantine Florio was bought by the Illva Saronno Corporation, which 
has undertaken an ambitious renovation of the property. It restored the cellars to their 19th-century glory. The six wine making halls, each longer than a football field, have vaulted cathedral ceilings with wooden beams. Beneath them, the wine is aged in large and small oaken casks that exude the charm of yore. A baronial table in the tasting hall seats 50, and the wine shop has the rarefied ambience of a designer boutique. Some 50,000 visitors a year make a pilgrimage to the winery, which has helped to revitalize wine tourism throughout the province. It has become one of the premier wine destinations in Italy.

The last example of a great wine destination is Castello di Brolio, a property that has belonged to the noble Ricasoli family since the 12 th century. In the 19th century, Baron Bettino Ricasoli, Minister of Agriculture and later Prime Minister, conducted experiments and research in his ancestral vineyards, and in 1874, he created the blend of grapes we know as "Chianti". Brolio is the fourth oldest wine estate in the world and dates back to 1142 . The 32nd baron, Francesco Ricasoli, is the current head of his dynasty and its wine business. He has created a museum that celebrates Baron Bettino - "the father of Chianti" - housed in apartments originally reserved for visits from the king. While the medieval castle (which received a neo-Gothic overhaul in Victorian times) is not open to visitors, they can admire the Renaissance gardens, and tour the winery. Baron Francesco has invested some 6 million Euros in a new fermentation facility, and Brolio, like Florio, attracts some 50,000 wine tourists a year.

In conclusion, we can say that the combination of a winery's venerable history, strong identity, a splendid edifice, and signature products of great quality and tradition create a unique magnet for tourists.

\section{The bigger picture}

Italy has 383,000 wine-producing estates. The average size of their vineyards is 1.64 hectares (two and a half acres). In 2013, the country's total wine production was 44 million hectoliters $(1,186,000,000$ gallons). There are 25,000 winebottling estates. Small estates, however, only account for $20 \%$ of the Italian wine that is sold internationally. Eighty percent is produced by the 500 major cooperative or industrial firms.

Wine tourism, however, depends largely on the mosaic of small producers, mostly situated in prestigious areas, many of whom bottle the wine of their own vineyards. (Only 25,000 wineries have private labels.) These are the wineries that offer tourists the pleasure of personal contact and authentic atmosphere that keeps them coming.
Areas such as Montalcino attract a constant flow of wine lovers, mainly foreigners who return every year to the same winery and its warm hospitality. The diversity of the small wineries is another factor. Each one bears the imprint of the generations - fathers, sons, and daughters, in a few cases who have cultivated their grapes with hands-on passion. They contrast starkly to the factory-like installations and to the impersonal wine supermarkets that are so similar the world over.

\section{Wine tourism business}

Of the 73 billion Euros spent annually by tourists in Italy, nearly 12 billion (16.1\%) are spent on wine and foodstuffs, including cheese, cured meats, and olive oil. A third of all visitors take home an edible or drinkable souvenir, at an average expenditure of 10 Euros.

Direct sales in winery shops account for $10 \%-20 \%$ of the vineyards' total business. The percentage tends to be higher on the smaller estates. A 2014 survey of 25 major wineries revealed that $8.4 \%$ of their business came from direct on-site wine sales, a figure that increases to $16.6 \%$ for prestigious wines. ${ }^{2}$

Wine tourists, however, are not the only direct buyers. One out of every three Italians buys wine where it is produced, with a natural preference for the wines of his or her region. The recent economic crisis has increased local shopping. Of these native clients, $31 \%$ are attracted by the price/quality ration of wines bought directly from a local vintner. This statistic has decisive importance for cooperative wineries. A poll of Italian consumers reveals that a quarter of them stress the importance of guaranteed provenance - an official denominazione di origine controllata. Another $24.9 \%$ are gratified and reassured by knowing the producer personally. ${ }^{3}$

A growing segment of the business, however, is in direct sales of organic or biodynamic wines. Of these consumers, $72 \%$ - about $8.8 \%$ of the Italian wine-savoring public - prefer buying directly from a winery. As a general rule, they drink a bottle every week, spending between 10 and $15 €$.

Wine tourism generates other profit points beyond the sale of bottles or cases. According to the CST survey carried out in 2012 for the Movimento del Turismo del Vino, for every $50 €$ spent on wine, the oenophile spends again as much for other wine-related products, wine-paired meals, souvenirs, and services. According to Censis for every euro spent on wine, oenophiles spend $5 €$ on eating, shopping, visiting museums, and generally speaking on any other attraction offered by the area. 


\section{The web and wine tourism}

According to statistics compiled by the Osservatorio del Turismo del Vino, the Internet has overtaken word-ofmouth as the most successful medium for promoting wine tourism. Word-of-mouth, however, remains a potent vehicle. Institutional promoters - travel agencies, press tourist offices, magazines, and guidebooks are far behind - have always only made a modest contribution to the trade. One exception is the "Cantine Aperte" (Open Cellars), a national wine celebration day that was launched in 1993, which continues to generate excitement and business.

Foreign wine tourists have a pronounced affinity for doing their vacation planning on the Internet and via social media six times more so than the average Italian. ${ }^{4} \mathrm{~A}$ survey carried out by Confesercenti Siena by Poste Italiane in January 2014, revealed that online searches for "Tuscany" were linked to searches for "wine" (21\%), "winery" (9.7\%), and "winery tours" (13\%.) English-speakers, with Americans at the top of the list, outstrip other nationals in typing "Tuscany" into their search windows (31\%). If we narrow the search to "Siena", the figure reaches $64 \%$. British, Canadian, and Australian users bring the total to over $90 \%$.

The Internet does more than provide booking information. It also fosters virtual communities of wine-lovers. They compare notes, trade stories, and share their passions on the many wine blogs and chat rooms. This digital word-of-mouth (or word-ofclick) is increasingly important to Italian wine tourism.

The Internet is vital to the wine industry for another reason - a geographical one. The small wineries are notoriously hard to find! Where wineries are concerned, Italian road signage is rather unhelpful. The Highway Code does not allow them to post closely spaced billboards along the routes that tourists have to follow, which are often serpentine and confusing. And the situation is particularly difficult where a high density of small enterprises cluster at a crossroads. GPS becomes essential. It is a modern-day shepherd that gathers the flock.

Unfortunately, many wineries do not seem to care sufficiently about their Internet profiles. A survey of 276 wine importers from 12 nations, conducted by Italy Fine Wines, in 2013 , revealed that $83 \%$ of them judged the Italian wineries' websites inferior to those of other countries. Of the importers, $9 \%$ receive regular news and updates from the wineries outside of - but not from - Italy. A survey by Fleishman Hillard Italia, conducted in November 2013, that focused on the 25 major Italian wineries, underlined a disappointing situation. Their websites were unattractive, or hard to navigate, or uninformative - quantity over quality. Only $34 \%$ of wineries had posted a video in the last 6 months. So Italians are missing out on, or misusing, a vital medium for transforming the casual wine tourist into a faithful return client.

The Italian Strade del Vino - wine routes - also use the Web too little and not well. Only about 20 of the 170 authorized associations are really functional. In most cases, the wine routes just print brochures and take part in the odd tasting fair, but they do not have an information office open to the public. In the last 2 years, there have been a few more translations and a better use of social networks but there is plenty of room for improvement. A 2013 survey conducted by the Osservatorio del Turismo del Vino (Censis Servizi per Ass) revealed, however, that $67 \%$ of them were satisfied by the promotional activities of the wine route organizers.

\section{Disclosure}

The author reports no conflicts of interest in this work.

\section{References}

1. Istituto Nazionale Ricerche turistiche. Available from: http://isnart it/rassegnaStampa_elenco.php?totrec $=3978 \&$ startRec $=1970 \&$ PHPSESSID=. Accessed April 2, 2015.

2. Mediobanca. Indagine Sul Settore Vinicolo [Wine sector survey] 2014. Available from: http://www.mbres.it/sites/default/files/resources/ download_it/Indagine_vini_2014.pdf. Accessed April 13, 2015.

3. Comunicare Il Vino. Vino, futuri possibili; il secondo rapporto sulla filiera. Available from: http://comunicareilvino.it/index.php/2013/07/ vino-futuri-possibili-il-secondo-rapporto-sulla-filiera/. Accessed April 13,2015 .

4. Indagine quali-auantitativa: Il volto dell'enoturista oggi. Available from: http://www.movimentoturismovino.it/it/news/nazionali/0/0/466/ indagine-quali-auantitativa-il-volto-dell-enoturista-oggi/. Accessed April 13, 2015.
International Journal of Wine Research

\section{Publish your work in this journal}

The International Journal of Wine Research is an international, peer-reviewed open-access, online journal focusing on all scientific aspects of wine, including: vine growing; wine elaboration; human interaction with wine; and health aspects of wine. The journal provides an open access platform for the reporting

\section{Dovepress}

of evidence based studies on these topics. The manuscript management system is completely online and includes a very quick and fair peer-review system, which is all easy to use. Visit http://www.dovepress.com/testimonials.php to read real quotes from some of our published authors. 